\title{
Influence of diet on copepod survival in the laboratory
}

\author{
M. Koski ${ }^{1,2,3, *}$, W. C. M. Klein Breteler ${ }^{1}$ \\ ${ }^{1}$ Royal Netherlands Institute of Sea Research, PO Box 59, 1790 AB Den Burg, Texel, The Netherlands \\ ${ }^{2}$ Department of Ecology and Systematics, Division of Hydrobiology, PO Box 17 (Arkadiankatu 7), \\ University of Helsinki, 00014 Helsinki, Finland
}

${ }^{3}$ Present address: Danish Institute for Fisheries Research, Kavalergården 6, 2920 Charlottenlund, Denmark

\begin{abstract}
The mortality rate of female calanoid copepods Temora longicornis and Pseudocalanus elongatus was measured in relation to the concentration of different algae as a food source. Female copepods were fed either good-quality food (Rhodomonas sp.) or nutritionally poor food (Dunaliella

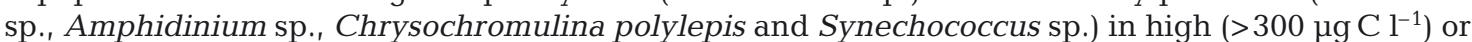
low $\left(<100 \mu \mathrm{g} \mathrm{C}^{-1}\right)$ concentrations and survival was monitored. Both copepod species had low mortality rates $\left(\leq 5 \% \mathrm{~d}^{-1}\right)$ when fed with a high concentration of Rhodomonas sp. or Dunaliella sp., somewhat higher rates with the same species at a low concentration $\left(4\right.$ to $\left.12 \% \mathrm{~d}^{-1}\right)$, and highest rates with all the other algae (12 to $\left.18 \% \mathrm{~d}^{-1}\right)$, irrespective of the concentration. Hence, some poor-quality algae can supply part or all of the energy required for survival. Diet-specific differences were more pronounced at high than at low food concentrations, suggesting that at low concentrations, qualitative differences of the algal food source decrease. The clearest copepod-specific difference was observed in survival without food: probably due to internal energy reserves, $P$. elongatus survived in filtered water nearly twice as long as T. longicornis. We suggest that, in low food environments, food quantity and species-specific ability to resist starvation might be as important as food quality in determining the success of copepod populations.
\end{abstract}

KEY WORDS: Copepod - Survival · Food quality - Temora longicornis · Pseudocalanus elongatus · Mortality $\cdot$ Food quantity

\section{INTRODUCTION}

Population dynamics of copepods are more sensitive to variations in mortality than to variations in fecundity. Population growth can be maintained at very low fecundity and/or very high egg mortality rates, whereas a relatively small increase in female mortality can cause negative population growth (Kiørboe 1998). Therefore, small changes in mortality rates of females may considerably improve the fitness of a population (Ohman \& Wood 1995).

Copepod mortality is affected by predation, starvation, parasitism and senescence (Ohman \& Wood 1995). Even though predation is likely to be the biggest cause of mortality in nature (Verity \& Smetacek 1996), food condition and temperature also affect female longevity (Ianora 1998). Whereas an increase in temperature seems to generally shorten the life span (Uye 1988), observations on the effect of diet are more controversial. Food concentrations ranging from 30 to $200 \mu \mathrm{g} \mathrm{Cl}^{-1}$ had little or no effect on the adult survival of Pseudocalanus elongatus (Paffenhöfer \& Harris 1976), but the mortality of Centropages typicus was elevated in low food concentrations (Davis \& Alatalo 1992). Food type has had an effect on adult survival in some cases (Gill \& Harris 1987, Ianora \& Poulet 1993), whereas no effect has been observed in other studies (Ianora et al. 1996), implying that the food species was not directly toxic to copepods. The effect of food type on survival is also related to food concentration: Paf- 
fenhöfer (1976) observed an increase in mortality at low food concentration with the diatom Lauderia borealis, whereas a similar low concentration of the dinoflagellate Prorocentrum micans supported high survival. Similarly, survival of Eurytemora affinis was high at $50 \mu \mathrm{g} \mathrm{C}^{-1}$ when fed with the green algae Brachiomonas submarina, but with a non-toxic strain of a nutritionally poor cyanobacterium, a similarly high survival was only obtained at food concentrations above $400 \mu \mathrm{g} \mathrm{C} \mathrm{l}^{-1}$ (Koski et al. 1999).

The effect of food quantity and quality on copepod survival is species-specific to the predator concerned: the same food species can induce both low and high survival in different copepods (see Gill \& Harris 1987, Ianora 1998). This effect could be connected to the copepods' species-specific feeding habits, adaptations to food, nutritional demands or tolerance for certain harmful or toxic substances. Species-specific effects of food quantity may, in turn, be connected to the copepods' ability to resist starvation, due to, e.g., storage of reserve lipids. Copepod species can differ in amount and type of lipid content. Some species, such as Calanus spp. or Pseudocalanus spp., contain high amounts of wax-esters that are suitable for long-term energy storage. Other species, like Temora longicornis and Acartia spp., mainly contain triacylglycerol, which only reflects the recent nutritional condition (Håkanson 1984, Fraser et al. 1989, Båmstedt et al. 1990). Thus, survival of species containing large reserves in the form of wax-esters should be less affected by food concentration than that of species containing minor amounts of triacylglycerol or other lipids.

Despite the large effect of female survival on population recruitment (Kiørboe 1998), and although there is abundant literature on the effect of food quality on copepod production (reviewed by Mauchline 1998), only a few studies have considered copepod mortality in relation to their food supply (Paffenhöfer \& Harris 1976, Hart 1996, Lopez 1996, Amarasinghe et al. 1997); in addition, very few studies have reported mortality rates of adult life-stages in relation to their food supply (Gill \& Harris 1987, Ianora 1998 and references therein). Therefore, at present nearly no systematic information is available on the effect of diet on adult survival in different copepod species. Since crustacean survival mainly depends on the availability of energy required for maintenance metabolism (Sterner \& Robinson 1994), it should, in principle, be relatively independent of the biochemical and mineral composition of food, assuming that the available food is edible, can be assimilated, and is not toxic. However, the previous studies show diet-specific survival rates (reviewed by Ianora 1998) and compensation of quality by quantity (Paffenhöfer 1976, Koski et al. 1999). We wanted to study this controversy by testing the depen- dency of copepod survival on food quality at different food concentrations, and by comparing the responses of 2 copepod species (Temora longicornis and Pseudocalanus elongates) differing in their dominant reserve lipids. We aimed to reveal whether (1) there are dietand/or copepod-specific differences in survival, and (2) these differences are dependent on food concentration.

\section{MATERIALS AND METHODS}

One to 5 replicate survival experiments were conducted with the 2 copepod species Temora longicornis and Pseudocalanus elongates feeding on 5 different algae species: the cryptophyte Rhodomonas sp., the green alga Dunaliella sp., the dinoflagellate Amphidinium sp., the prymnesiophyte Chrysochromulina polylepis and the cyanobacterium Synechococcus sp. The algae were supplied to copepods as a singlespecies diet, either at a high (300 to $800 \mu \mathrm{g} \mathrm{C} \mathrm{l}^{-1}$ ) or low (40 to $120 \mu \mathrm{g} \mathrm{C}^{-1}$ ) concentration. A carbon concentration of $\geq 300 \mathrm{\mu g} \mathrm{C}^{-1}$ is sufficient in the diet for maximum growth of both copepod species (Klein Breteler \& Gonzalez 1986, Klein Breteler et al. 1995). In addition, experiments were conducted in $<2 \mu \mathrm{m}$ filtered seawater (Whatman Gamma 12-20), to determine mortality rates due to starvation. Rhodomonas sp. is known to be a good-quality food-source for copepods (Klein Breteler 1980), whereas all the other species generally induce low growth or decreased egg production (Koski et al. 1998 and references therein, Koski et al. unpubl.). However, adults of T. longicornis and P. elongatus feed on Dunaliella sp. and Amphidinium sp. with equal intensity as on Rhodomonas sp. (Koski et al. 1998, M. Koski, W. C. M. Klein Breteler, N. Schogt unpubl. data). The nutritional properties of the algae (polyunsaturated fatty acids and sterols, as well as potential toxicity) and their effect on copepod feeding, growth and reproduction are listed in Table 1.

Copepods were reared in the laboratory at $15^{\circ} \mathrm{C}$, with excess food consisting of a mixture of the flagellates Rhodomonas sp., Isochrysis galbana and Oxyrris marina (Klein Breteler 1980, Klein Breteler et al. 1982). Individuals used in the experiments originated from a recently (less than $4 \mathrm{~d}$ before) matured generation. Prior to the experiments, ca. 40 females were carefully selected using a dissecting microscope and placed into 1.21 bottles containing the experimental food suspension. Copepods and prey were kept in suspension by rotating at $1 \mathrm{rpm}$. Food was supplied daily by renewing ca. $80 \%$ of the experimental water, using reverse filtration with a $50 \mu \mathrm{m}$ net. The food concentration in the bottles was regularly checked with an ELZONE electronic particle counter (Particle Data) and the food 
level between feeding intervals never decreased by more than $30 \%$ of the initial concentration. Every 3 to $4 \mathrm{~d}$ the content of each bottle was carefully filtered onto a $300 \mu \mathrm{m}$ net and flushed into a petri-dish. Dead individuals were counted using a dissecting microscope and removed, and the remaining copepods were placed back into the experimental bottles. The experiments were terminated after 2 to $4 \mathrm{wk}$, depending on the survival of the copepods.

All algae species were cultured in chemostats with $\mathrm{F} / 2$ medium (Guillard 1975 ) at $15^{\circ} \mathrm{C}$ and a light intensity of ca. $150 \mu \mathrm{E} \mathrm{m}^{-2} \mathrm{~s}^{-2}$, on a 16:8 h light:dark cycle. The dilution rate of all cultures was kept at $\sim 0.2 \mathrm{~d}^{-1}$. The mean cell volume of the algae was measured with the ELZONE counter. The particulate organic carbon and nitrogen content of the algae was measured with a Carlo Erba CHN analyser after filtering 1 to $10 \mathrm{ml}$ of algal culture onto a combusted Whatman GF/C filter $\left(450^{\circ} \mathrm{C}\right.$ for $\left.4 \mathrm{~h}\right)$ and storing at $-50^{\circ} \mathrm{C}$. The carbon content of Synechococcus sp. was estimated based on the carbon content of Dunaliella sp., and corrected for mean cell volume. Volume, carbon and nitrogen content and the C:N ratio of each algal species, as well as the average food concentrations used in the experiments and the number of replicates, are given in Table 2.

Copepod mortality during the experiments was relatively constant (cf. Figs. 1 \& 2), and was described by:

$$
N_{t}=N_{0} \mathrm{e}^{-Z t}
$$

where $N_{0}$ is the number of individuals at Time $0\left(1^{-1}\right), N_{t}$ is the number of individuals at time $t$, and $Z$ is the instantaneous rate of mortality. Thus, mortality $\left(\% \mathrm{~d}^{-1}\right)$ was derived from the slope of the linear regression of ln-number of individuals against time (cf. Figs. 1 \& 2). The mortality rate was estimated separately for each replicate experiment (cf. Figs. $1 \& 2$, Table 3), and the replicate experiments were preliminarily tested for differences using ANCOVA, using the interaction between experiment (treatment) and day (covariate). Since the replicate experiments, with a few exceptions (cf. Table 3), did not differ significantly from each other, the data were pooled for further ANCOVA.

The mortality rates were tested for differences among diets with ANCOVA, using the interaction between the diet (treatment) and day (covariate), separately for high and low food concentrations and the 2 copepod species. The pairwise differences were tested using Tukey's a posteriori test following 1-way ANOVA on the slopes of the linear regressions of replicate experiments. In addition, the mortality rates were tested for differences among the 2 copepod species with a 2-way ANOVA on the slopes of replicate experiments (using copepod species and diet as independent variables). All data were tested for normal distribution and homogeneity of variances. All analyses were conducted using SYSTAT 7.0 statistical package.

\section{RESULTS AND DISCUSSION}

The mortality of Temora longicornis depended on diet, both at high (ANCOVA diet $\times$ day; $F_{4,32}=6.9$; $<<$ $0.0001)$ and low $\left(F_{4,38}=3.0 ; \mathrm{p}<0.05\right)$ concentrations. At a high concentration, mortality was significantly lower with Rhodomonas sp. (on average $2.1 \pm 0.9 \% \mathrm{~d}^{-1}$ ) and

Table 1. Nutritional properties (presence of the long-chain polyunsaturated fatty acids linolenic acid 18:3 $\omega 3$, eicosapentaenoic acid [EPA] and DHA and sterols) and potential toxicity of the algal species used in experiments, as well as ingestion, growth and reproduction of copepods fed on these algae. +: nutritional component present, algae ingested, good growth and reproduction; -: nutritional component absent, algae rejected, no growth or reproduction; $\mathrm{f}$ : algae potentially toxic. Lipid measurements on Rhodomonas sp., Dunaliella sp., Amphidinium sp. (no sterols) and Chrysochromulina polylepis (no sterols) were conducted with the same strain of algae as was used in the present experiments (Klein Breteler et al. 1999, W. C. M. Klein Breteler, S. Schouten, M. Baas unpubl. data)

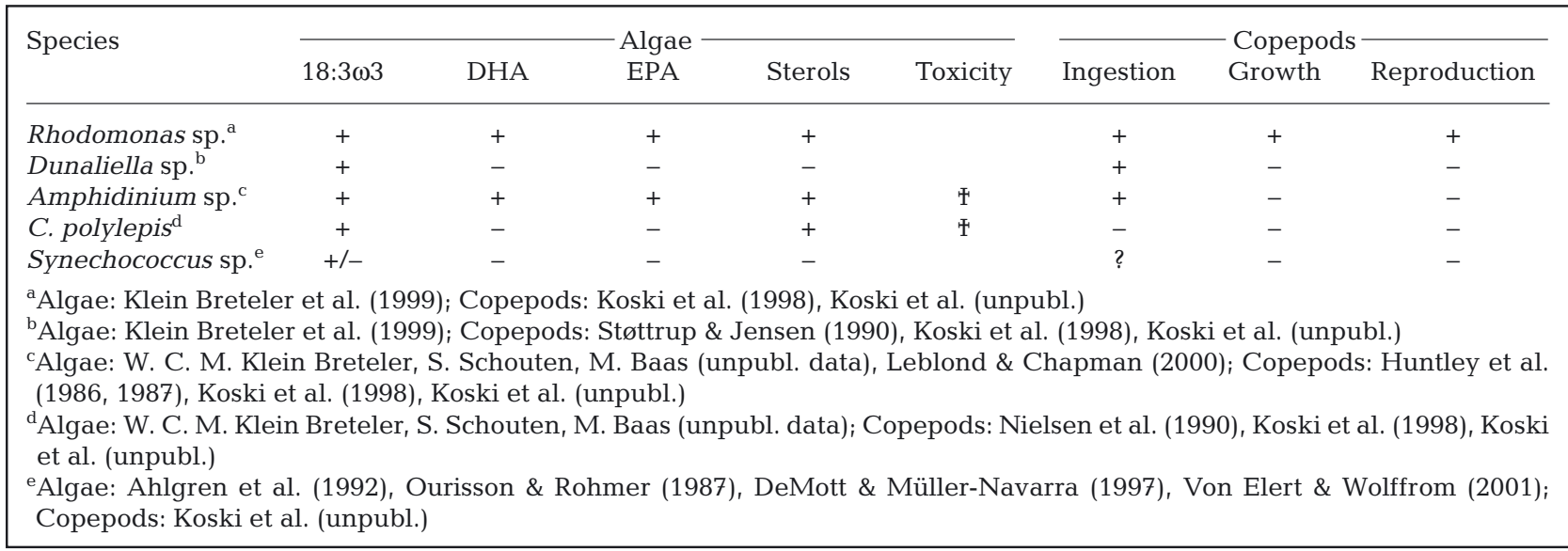


Table 2. Volume, carbon content and C:N ratio of algae, food concentration in number of cells and in carbon, and number of replicate experiments at high (300 to $700 \mu \mathrm{g} \mathrm{C}^{-1}$ ) and low food concentrations (40 to $\left.120 \mu \mathrm{g} \mathrm{C} \mathrm{l}^{-1}\right)$, and with no food $(<2 \mu \mathrm{m}$ filtered seawater). Rho: Rhodomonas sp.; Du: Dunaliella sp.; Amp: Amphidinium sp.; Chry: Chrysochromulina polylepis; Syn: Synechococcus sp.; Fw: filtered seawater. -: missing data; no entry: no experiment carried out

\begin{tabular}{|c|c|c|c|c|c|c|c|c|c|}
\hline \multirow{2}{*}{$\begin{array}{l}\text { Food } \\
\text { species }\end{array}$} & \multirow[b]{2}{*}{$\begin{array}{c}\text { Volume } \\
\left(\mu \mathrm{m}^{3} \text { cell }^{-1}\right)\end{array}$} & \multirow{2}{*}{$\begin{array}{c}\text { - Algae }- \\
\text { Carbon } \\
\left(\mu \text { cell }^{-1}\right)\end{array}$} & \multirow[b]{2}{*}{$\begin{array}{c}\text { C:N } \\
\text { (molar) }\end{array}$} & \multicolumn{3}{|c|}{ Temora longicornis } & \multicolumn{3}{|c|}{ —Pseudocalanus elongatus —- } \\
\hline & & & & $\begin{array}{l}\text { No. of cells } \\
\left(\mathrm{ml}^{-1}\right)\end{array}$ & $\begin{array}{l}\text { Carbon } \\
\left(\mu \mathrm{g} \mathrm{l}^{-1}\right) \mathrm{r}\end{array}$ & $\begin{array}{l}\text { No. of } \\
\text { replicates }\end{array}$ & $\begin{array}{l}\text { No. of cells } \\
\left(\mathrm{ml}^{-1}\right)\end{array}$ & $\begin{array}{l}\text { Carbon } \\
\left(\mu \mathrm{g} \mathrm{l}^{-1}\right) \mathrm{r}\end{array}$ & $\begin{array}{l}\text { No. of } \\
\text { replicates }\end{array}$ \\
\hline \multicolumn{10}{|c|}{ High food conc. } \\
\hline Rho & $156 \pm 0$ & $36 \pm 0.2$ & $4.2 \pm 0.01$ & $9500 \pm 1200$ & $340 \pm 40$ & 3 & $9500 \pm 1100$ & $340 \pm 40$ & 2 \\
\hline $\mathrm{Du}$ & $156 \pm 0$ & $27 \pm 5.1$ & $5.0 \pm 0.2$ & $25000 \pm 320$ & $670 \pm 9$ & 2 & $28000 \pm 3700$ & $760 \pm 100$ & 2 \\
\hline Amp & $535 \pm 0$ & $141 \pm 2.6$ & $5.1 \pm 0.01$ & $3500 \pm 250$ & $500 \pm 36$ & 1 & $3700 \pm 110$ & $520 \pm 16$ & 1 \\
\hline Chry & $170 \pm 0$ & $26 \pm 1.0$ & $8.6 \pm 0.3$ & $27000 \pm 1400$ & $690 \pm 40$ & 1 & & & \\
\hline Syn & $26 \pm 13$ & $4.5 \pm 2.2$ & - & $68000 \pm 24000$ & $310 \pm 110$ & 1 & & & \\
\hline \multicolumn{10}{|c|}{ Low food conc. } \\
\hline Rho & $156 \pm 0$ & $36 \pm 0.2$ & $4.2 \pm 0.01$ & $1100 \pm 600$ & $40 \pm 20$ & 3 & $1400 \pm 200$ & $50 \pm 7$ & 2 \\
\hline $\mathrm{Du}$ & $156 \pm 0$ & $27 \pm 5.1$ & $5.0 \pm 0.2$ & $2900 \pm 800$ & $78 \pm 23$ & 3 & $3500 \pm 470$ & $94 \pm 13$ & 2 \\
\hline Amp & $535 \pm 0$ & $141 \pm 2.6$ & $5.1 \pm 0.01$ & $480 \pm 35$ & $68 \pm 4.9$ & 1 & $470 \pm 49$ & $66 \pm 7$ & 1 \\
\hline Chry & $170 \pm 0$ & $26 \pm 1.0$ & $8.6 \pm 0.3$ & $4600 \pm 450$ & $120 \pm 10$ & 1 & & & \\
\hline Syn & $26 \pm 13$ & $4.5 \pm 2.2$ & - & 9600 & 43 & 1 & & & \\
\hline \multicolumn{10}{|l|}{ No food } \\
\hline FW & & & & & & 5 & & & 2 \\
\hline
\end{tabular}

Dunaliella sp. $\left(2.5 \pm 0.3\right.$ or $\left.1.3 \pm 0.4 \% \mathrm{~d}^{-1}\right)$ than with Amphidinium sp. $\left(12 \pm 1.5 \% \mathrm{~d}^{-1}\right)$, Chrysochromulina polylepis $\left(12 \pm 2.3 \% \mathrm{~d}^{-1}\right)$ or Synechococcus sp. $(15 \pm$ $2.8 \% \mathrm{~d}^{-1}$ ) (Tukey's HSD on slopes; $\mathrm{p}<0.05$ ). At a low concentration, the differences in mortality rates among food species were not significant (Tukey's HSD; p > $0.05)$, although clearly lower mortality was obtained on Rhodomonas sp. (on average $8.4 \pm 1.8 \% \mathrm{~d}^{-1}$ ) and Dunaliella sp. (on average $3.7 \pm 0.8 \% \mathrm{~d}^{-1}$ ) than on the other food species $\left(14 \pm 1.8,15 \pm 2.1\right.$ and $18 \pm 1.9 \% \mathrm{~d}^{-1}$ for Amphidinium sp., C. polylepis and Synechococcus sp., respectively). Rhodomonas sp. and Dunaliella sp. also induced mortality, which was significantly lower than that in filtered seawater $\left(24 \pm 3 \% \mathrm{~d}^{-1}\right.$; Tukey's HSD; $\mathrm{p}<0.01$ ) (Fig. 1, Table 3). With a mortality of $<2.5 \% \mathrm{~d}^{-1}$, observed at high concentrations of Rhodomonas sp. and Dunaliella sp., the female longevity (ca. $40 \mathrm{~d}$ ) corresponds to previous reports on maximum female longevity of Temora spp. (Harris \& Paffenhöfer 1976, Ianora \& Poulet 1993).

The mortality of Pseudocalanus elongatus was measured at high and low concentrations of Rhodomonas sp., Dunaliella sp. and Amphidinium sp. and in filtered seawater alone (Fig. 2). Similarly to Temora longicornis, there were significant differences in mortality rates among diets both at high $\left(F_{2,27}=6.6 ; \mathrm{p}<0.01\right)$ and low $\left(F_{2,26}=7.7 ; \mathrm{p}<0.01\right)$ food concentrations, although the differences among the different diets and starvation were smaller. Lowest mortality rates were obtained at high concentrations of Rhodomonas sp. (on average $4.1 \pm 0.9 \% \mathrm{~d}^{-1}$ ) and Dunaliella sp. (on average $\left.5.3 \pm 1.4 \% \mathrm{~d}^{-1}\right)$, and a somewhat higher mortality rate was seen at a low concentration of the same species (respectively $6.2 \pm 1$ and $11 \pm 1.9 \% \mathrm{~d}^{-1}$ ). The survival with both concentrations of Amphidinium sp. was not enhanced compared to filtered seawater alone (Fig. 2, Table 3). In short, there was a large effect of algal species on copepod mortality, which greatly exceeded the within-species effect of concentration (Fig. 3).

There were no significant differences in mortality rates between Temora longicornis and Pseudocalanus elongatus in any of the diets offered at a high concentration (2-way ANOVA; $\left.F_{2,5}=0.08 ; \mathrm{p}>0.05\right)$. However, mortality among the 2 copepod species was somewhat different at a low food concentration $\left(F_{2,6}=5.4 ; \mathrm{p}<\right.$ 0.05), likely due to the lower survival of $P$. elongatus at a low concentration of Dunaliella sp. (cf. Table 3). In addition, the copepod species reacted differently to starvation (filtered seawater): the mortality of $P$. elongatus was lower in filtered seawater alone than the mortality of $T$. longicornis $\left(F_{1,29}=6.2 ; \mathrm{p}<0.05\right)$ (Table 3$)$.

Similar to the studies reviewed by Ianora (1998), significant differences in copepod survival were detected among the different food species, although only if they were offered at high concentrations. The low survival rates on Synechococcus sp., Chrysochromulina polylepis and Amphidinium sp. may have been due to rejection of them as a toxic or low-quality food, as observed by Gill \& Harris (1987), even though the enhanced survival of Temora longicornis on these species, compared to filtered seawater, suggested that the algae were ingested at least to some extent. Also, previous feeding studies on Amphidinium sp. showed that this species is ingested by both copepod species (Koski et al. 1998, M. Koski, 

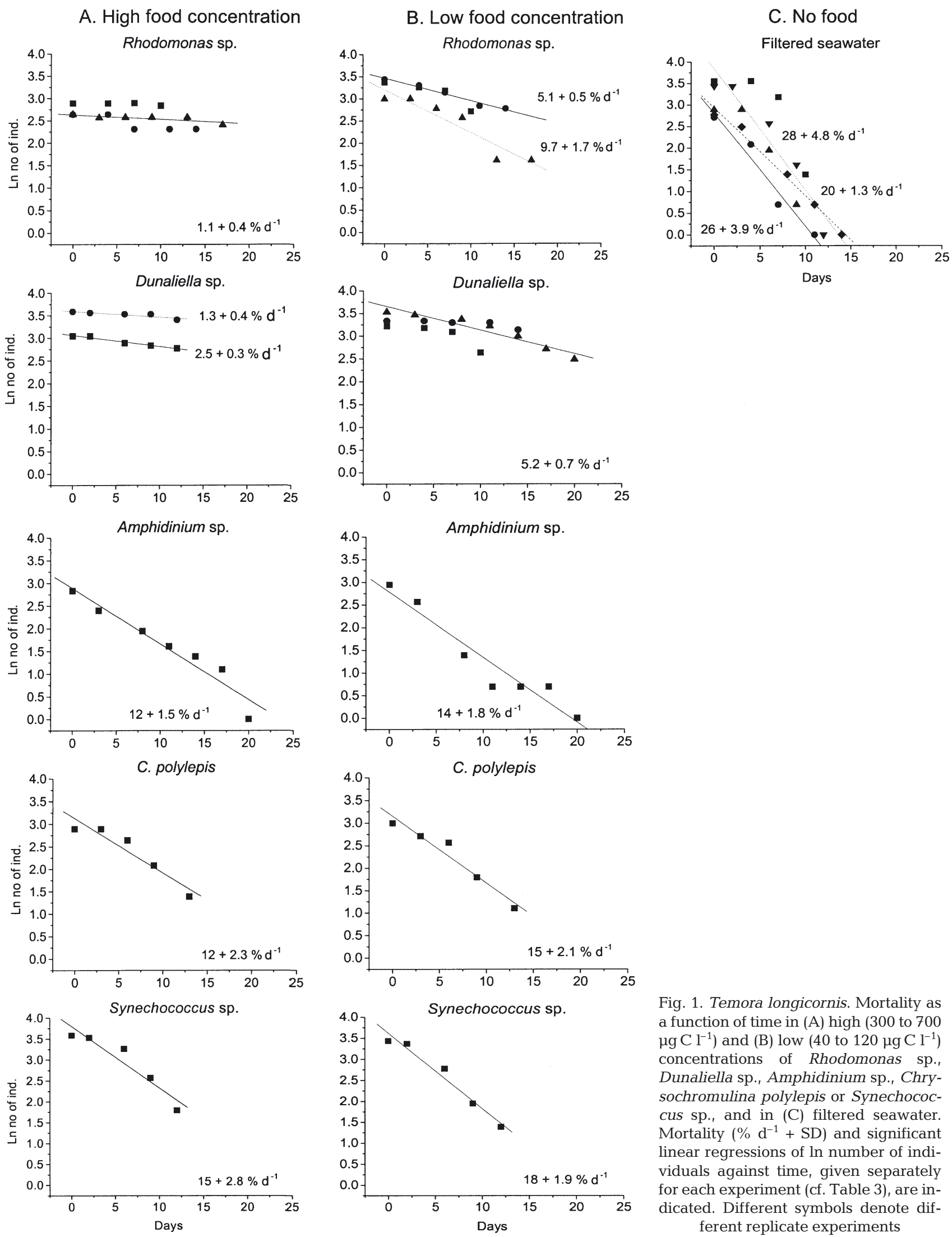

Fig. 1. Temora longicornis. Mortality as a function of time in (A) high (300 to 700 $\mu \mathrm{g} \mathrm{Cl}^{-1}$ ) and (B) low (40 to $120 \mu \mathrm{g} \mathrm{C} \mathrm{l}^{-1}$ ) concentrations of Rhodomonas sp., Dunaliella sp., Amphidinium sp., Chrysochromulina polylepis or Synechococcus sp., and in (C) filtered seawater. Mortality $\left(\% \mathrm{~d}^{-1}+\mathrm{SD}\right)$ and significant linear regressions of $\ln$ number of individuals against time, given separately for each experiment (cf. Table 3), are indicated. Different symbols denote different replicate experiments 

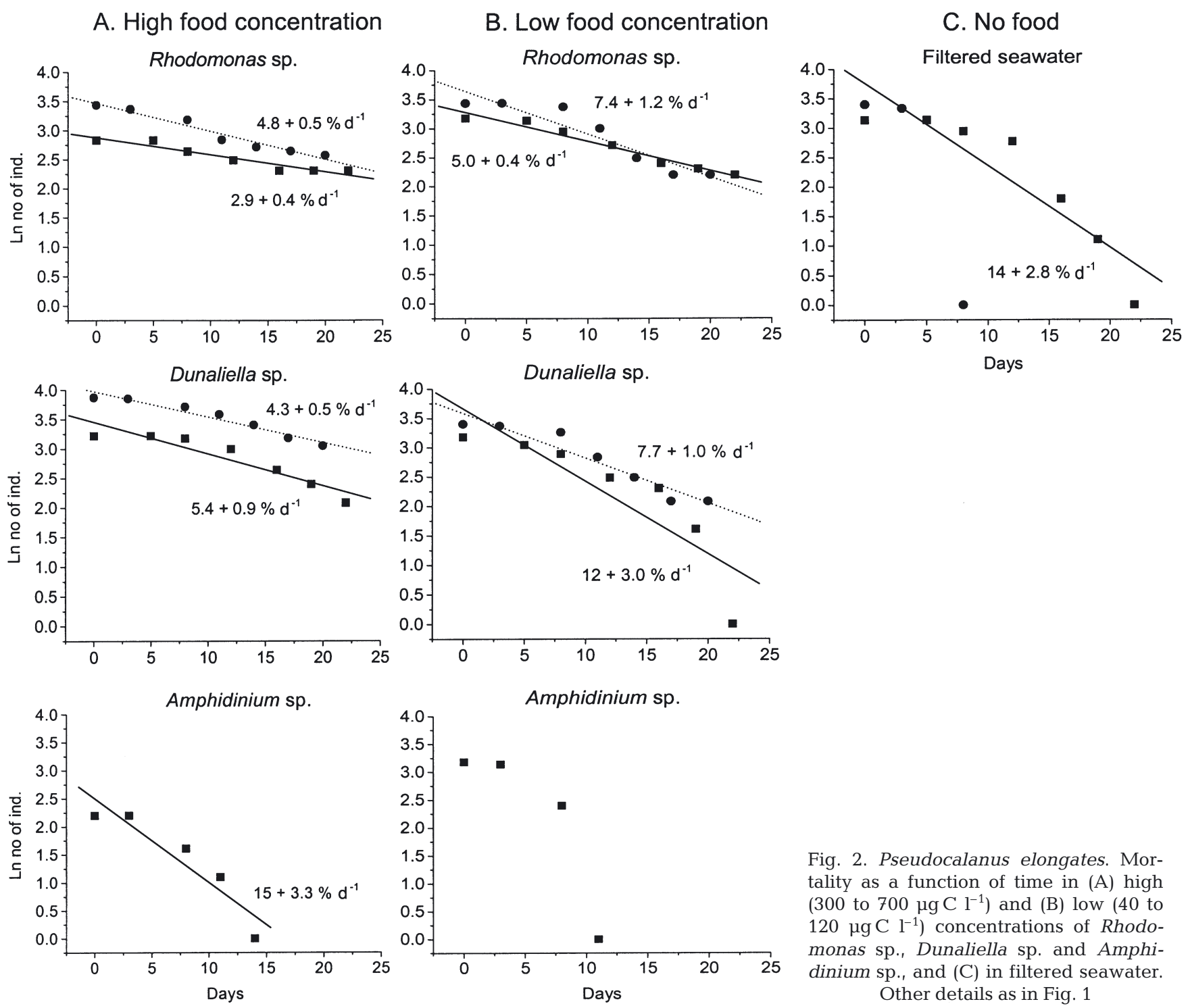

Fig. 2. Pseudocalanus elongates. Mortality as a function of time in (A) high (300 to $700 \mu \mathrm{g} \mathrm{C} \mathrm{l}^{-1}$ ) and (B) low (40 to $120 \mu \mathrm{g} \mathrm{C}^{-1}$ ) concentrations of Rhodomonas sp., Dunaliella sp. and Amphidinium sp., and $(\mathrm{C})$ in filtered seawater. Other details as in Fig. 1

W. C. M. Klein Breteler, N. Schogt unpubl. data). Apparently, Amphidinium sp., C. polylepis and Synechococcus sp. are of inferior quality also for survival, possibly due to the presence of some toxic or inhibitory substances (see Table 1 for details on Amphidinium sp. and C. polylepis) or some other quality affecting not only growth and reproduction, but also survival (cf. Ianora 1998). Further, with these food species, survival was not affected by food concentration, suggesting that the low quality could not really be compensated by a higher supply rate. Therefore, compensation of food quality with quantity (cf. Paffenhöfer 1976, Koski et al. 1999) seems to depend on species used as a food source.

In contrast to the other low-quality algae used in experiments, the survival on Dunaliella sp. was as high as on Rhodomonas sp., even though Dunaliella sp. is generally considered a nutritionally poor food (Støttrup \& Jensen 1990, Koski et al. 1998, Klein Breteler et al. 1999). Therefore, Dunaliella sp. seems to be an equally good source of energy as Rhodomonas sp. to support maintenance metabolism. This confirms the fact that survival does not require the same suit of elements essential for growth or reproduction (Sterner \& Robinson 1994). The contrast between high survival on Dunaliella sp. (polyunsaturated fatty acids [PUFAs] and sterols absent; see Table 1) and low survival on other poor-quality food species (variable content of PUFAs and sterols; Table 1) suggests that factors other than biochemical composition are responsible for the effect of food quality on survival.

When the algae were offered at a low concentration, the differences in female survival among diets de- 
creased, e.g. the differences in mortality rates (slopes in Figs. 1 \& 2) of Temora longicornis among different diets were not significant (Fig. 1B), which contrasted to the observations with high food concentrations (Fig. 1A). Therefore, the dependence of copepod survival on food quality was higher at high food concentrations than at low concentrations. This agrees with freshwater studies, showing that at low food concentrations, zooplankton is no longer food-quality limited (Hessen 1992, Urabe \& Watanabe 1993, Sterner \& Robinson 1994). Hence, if food concentration is too low to support growth or reproduction, copepod population dynamics should not be limited by food quality.

The largest differences in survival of the 2 copepod species were found in filtered seawater alone. It seems that Pseudocalanus elongatus is much better able to survive starvation than Temora longicornis. Mortality of T. longicornis in filtered seawater was high after only a few days and continued at a constant rate until Day 14, when all individuals had died. In contrast, nearly all $P$. elongatus were still alive after $12 \mathrm{~d}$ (with the exception of 1 observation where all animals were found dead on Day 8; cf. Fig. 2C), and a few individuals even survived until Day 22. This agrees with the observations of Dagg (1977) and Hassett \& Landry (1990), who found low starvation resistance in Acartia tonsa and Centropages typicus $(<10 \mathrm{~d})$, whereas Calanus finmarchicus, Calanus pacificus and Pseudocalanus minutus survived up to $3 \mathrm{wk}$ in the absence of food, which was expected based on the differences in the lipid content and type of the 2 copepod species. Whereas $P$. elongatus contains visible oil-sacs of mainly wax-esters, available as a long-term energy reserve, T. longicornis has few usable reserve lipids (Fraser et al. 1989, Båmstedt et al. 1990).

If neither food quality nor quantity is limiting, copepod mortality seems to be highest in early copepodite stages, followed by nauplii stages and adults (Paffenhöfer \& Harris 1976, Bonnet \& Carlotti 2001). How-

Table 3. Temora longicornis and Pseudocalanus elongatus. Parameters from the linear model of mortality, relating ln-number of individuals to time, separately for each experiment, as well as combining all experiments (see Figs. $1 \& 2$ ) at high ( 300 to $700 \mu \mathrm{g} C$ $\mathrm{l}^{-1}$ ) and low $\left(40\right.$ to $\left.120 \mu \mathrm{g} \mathrm{C} \mathrm{l}^{-1}\right)$ food concentrations, and with no food $(<2 \mu \mathrm{m}$ filtered seawater). (cf. Table 1$)$. The regression based on all data points (total) is printed in bold. ${ }^{*}$ : treatments with significant differences between replicate experiments

$($ ANCOVA; $\mathrm{p}<0.05)$. Abbreviations as in Table 2

\begin{tabular}{|c|c|c|c|c|c|c|c|c|c|c|}
\hline \multirow{2}{*}{$\begin{array}{l}\text { Food } \\
\text { species }\end{array}$} & \multicolumn{5}{|c|}{-Temora longicornis- } & \multicolumn{5}{|c|}{ Pseudocalanus elongatus } \\
\hline & Slope \pm SD & Intercept & $\mathrm{n}$ & $\mathrm{R}$ & $\mathrm{p}$ & Slope \pm SE & Intercept & $\mathrm{n}$ & $\mathrm{R}$ & $\mathrm{p}$ \\
\hline \multicolumn{11}{|c|}{ High food conc. } \\
\hline \multirow[t]{4}{*}{ Rho } & $-0.005 \pm 0.003$ & 2.90 & 4 & 0.74 & $>0.05$ & $-0.029 \pm 0.004$ & 2.87 & 7 & 0.96 & $<0.001$ \\
\hline & $-0.029 \pm 0.01$ & 2.64 & 5 & 0.86 & $>0.05$ & $-0.048 \pm 0.005$ & 3.46 & 7 & 0.98 & $<0.001$ \\
\hline & $-0.011 \pm 0.004$ & 2.63 & 6 & 0.83 & $<0.05$ & $-0.041 \pm 0.009^{*}$ & 3.19 & 14 & 0.80 & $<0.001$ \\
\hline & $-0.021 \pm 0.009$ & 2.75 & 15 & 0.53 & $<0.05$ & & & & & \\
\hline \multirow[t]{3}{*}{$\mathrm{Du}$} & $-0.025 \pm 0.003$ & 3.06 & 5 & 0.98 & $<0.01$ & $-0.054 \pm 0.009$ & 3.45 & 7 & 0.94 & $<0.01$ \\
\hline & $-0.013 \pm 0.004$ & 3.59 & 5 & 0.89 & $<0.05$ & $-0.043 \pm 0.005$ & 3.97 & 7 & 0.97 & $<0.001$ \\
\hline & $-0.019 \pm 0.024^{*}$ & 3.33 & 10 & 0.26 & $>0.05$ & $-0.053 \pm 0.014$ & 3.76 & 14 & 0.74 & $<0.01$ \\
\hline Amp & $-0.123 \pm 0.015$ & 2.89 & 7 & 0.97 & $<0.001$ & $-0.150 \pm 0.033$ & 2.50 & 5 & 0.93 & $<0.05$ \\
\hline Chry & $-0.121 \pm 0.023$ & 3.13 & 5 & 0.95 & $<0.05$ & & & & & \\
\hline Syn & $-0.147 \pm 0.028$ & 3.80 & 5 & 0.95 & $<0.05$ & & & & & \\
\hline \multicolumn{11}{|c|}{ Low food conc. } \\
\hline \multirow[t]{4}{*}{ Rho } & $-0.061 \pm 0.022$ & 3.45 & 4 & 0.89 & $>0.05$ & $-0.050 \pm 0.004$ & 3.28 & 7 & 0.98 & $<0.0001$ \\
\hline & $-0.051 \pm 0.005$ & 3.46 & 5 & 0.99 & $<0.01$ & $-0.074 \pm 0.012$ & 3.64 & 7 & 0.94 & $<0.01$ \\
\hline & $-0.097 \pm 0.017$ & 3.20 & 6 & 0.94 & $<0.01$ & $-0.062 \pm 0.01$ & 3.47 & 14 & 0.93 & $<0.0001$ \\
\hline & $-0.084 \pm 0.018$ & 3.42 & 15 & 0.80 & $<0.01$ & & & & & \\
\hline \multirow[t]{4}{*}{$\mathrm{Du}$} & $-0.053 \pm 0.023$ & 3.31 & 4 & 0.85 & $>0.05$ & $-0.124 \pm 0.030$ & 3.66 & 7 & 0.88 & $<0.01$ \\
\hline & $-0.012 \pm 0.005$ & 3.36 & 5 & 0.81 & $>0.05$ & $-0.077 \pm 0.010$ & 3.58 & 7 & 0.96 & $<0.001$ \\
\hline & $-0.052 \pm 0.007$ & 3.65 & 7 & 0.96 & $<0.001$ & $-0.105 \pm 0.019$ & 3.66 & 14 & 0.85 & $<0.0001$ \\
\hline & $-0.037 \pm 0.008^{*}$ & 3.44 & 16 & 0.76 & $<0.001$ & & & & & \\
\hline Amp & $-0.144 \pm 0.018$ & 2.78 & 7 & 0.96 & $<0.001$ & $-0.265 \pm 0.104$ & 3.63 & 4 & 0.87 & $>0.05$ \\
\hline Chry & $-0.148 \pm 0.021$ & 3.15 & 5 & 0.97 & $<0.01$ & & & & & \\
\hline Syn & $-0.179 \pm 0.019$ & 3.62 & 5 & 0.98 & $<0.01$ & & & & & \\
\hline \multicolumn{11}{|l|}{ No food } \\
\hline \multirow[t]{6}{*}{ FW } & $-0.200 \pm 0.097$ & 3.97 & 4 & 0.82 & $>0.05$ & $-0.140 \pm 0.028$ & 3.76 & 7 & 0.91 & $<0.01$ \\
\hline & $-0.261 \pm 0.039$ & 2.81 & 4 & 0.98 & $<0.05$ & $-0.450 \pm 0.171$ & 3.89 & 3 & 0.94 & $>0.05$ \\
\hline & $-0.251 \pm 0.068$ & 3.24 & 4 & 0.93 & $>0.05$ & $-0.132 \pm 0.044^{*}$ & 3.43 & 10 & 0.72 & $<0.05$ \\
\hline & $-0.282 \pm 0.048$ & 3.84 & 5 & 0.96 & $<0.01$ & & & & & \\
\hline & $-0.204 \pm 0.013$ & 2.93 & 5 & 0.99 & $<0.001$ & & & & & \\
\hline & $-0.241 \pm 0.030$ & 3.38 & 22 & 0.87 & $<0.001$ & & & & & \\
\hline
\end{tabular}



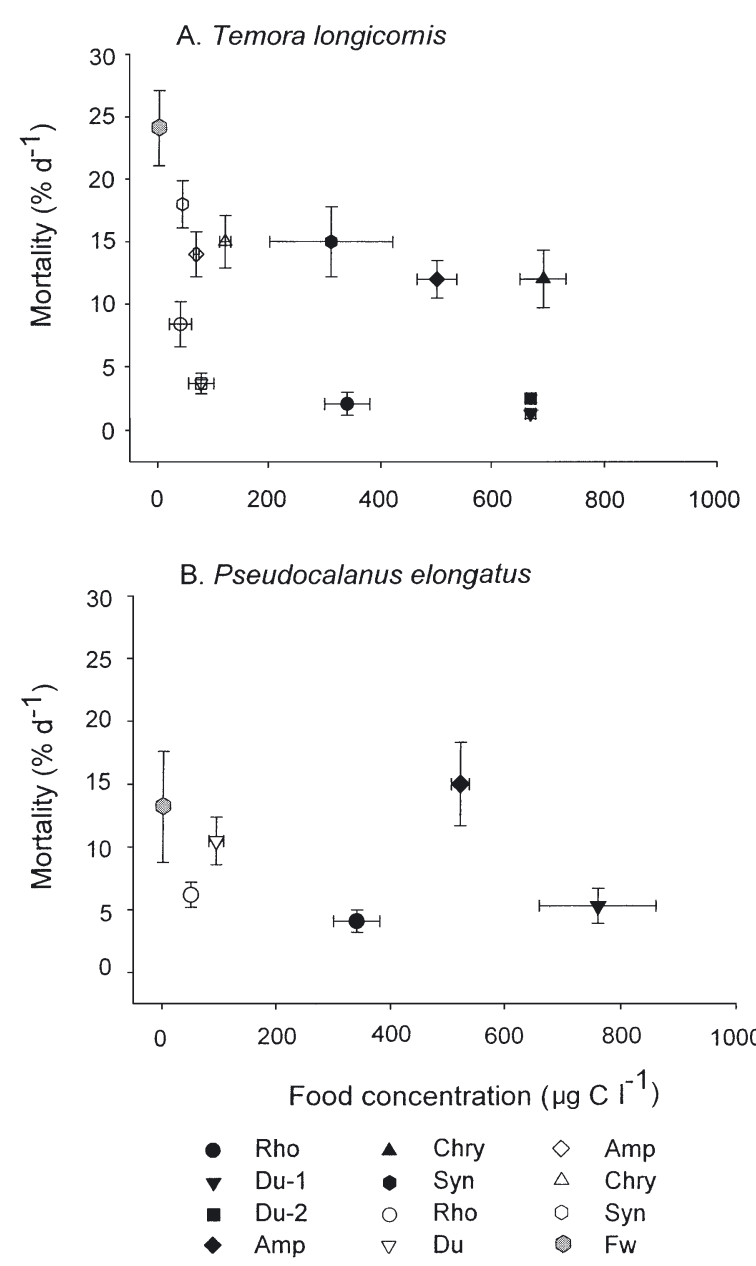

Fig. 3. (A) Temora longicornis and (B) Pseudocalanus elongatus. Mortality $\left(\% \mathrm{~d}^{-1}\right)$ as a function of food concentration (mean $\pm \mathrm{SE}$ ). The 2 experiments with $T$. longicornis and a high concentration of Dunaliella sp. (Du-1 and Du-2) are plotted separately, since the pooled regression was not significant (cf. Table 3). Closed symbols: high food concentration; open symbols: low food concentration; shaded symbols: filtered seawater. Different shapes indicate different food species. Rho: Rhodomonas sp.; Du: Dunaliella sp.; Amp: Amphidinium sp.; Chry: Chrysochromulina polylepis; Syn: Synechococcus sp.; Fw: filtered seawater

ever, in cases of food limitation or starvation, mortality is generally found to be highest in the early lifestages (Lopez 1991). Our observations agree with these observations: with a high concentration of Rhodomonas sp. the mortality rates of Temora longicornis and Pseudocalanus elongatus were ranked as copepodites > nauplii > adults, whereas with lowquality food species (including Dunaliella sp.), as well as at a low food concentration, nauplii mortality was always too high for any individual to reach the first copepodite stage, and always $>2$ times higher than mortality of adults (Table 4). This suggests that early life stages are more sensitive to limitations in food quantity and/or quality. It is possible that juvenile copepods, in contrast to adults, cannot survive on food that does not support growth, and will die if the available food source does not allow for molting to the next stage.

Our results demonstrate that, whereas growth and reproduction are likely to be dependent on food biochemistry and mineral composition (cf. Brett et al. 2000), copepod survival seems to be more related to other factors, such as the edibility and digestibility of the food source. However, at low food concentrations, there are few significant differences in the survival of adult copepods among the different food species offered, which suggests that copepod populations (due to the high effect of female survival on population dynamics; Kiørboe 1998) in low food environments may be less affected by food biochemistry. In coastal areas of the temporal and boreal seas, phytoplankton biomass tends to be low during most of the year (e.g. in

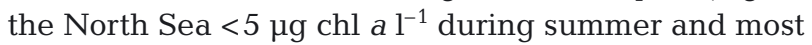
of the winter; Cadée \& Hegeman 1991, Peeters et al. 1993), which stresses the importance of both the effect of food quantity on survival and the species-specific ability to resist starvation in determining the success of different copepod species.

Table 4. (a) Temora longicornis and (b) Pseudocalanus elongatus. Comparison of mortality rates $\left(\% \mathrm{~d}^{-1}\right)$ of nauplii, copepodites and adults feeding on Rhodomonas sp., Dunaliella sp., Amphidinium sp., Chrysochromulina polylepis and Synechococcus sp., and with no food in filtered seawater (FW). With all diets, except for the high concentration of Rhodomonas sp., copepods died before reaching the first copepodite stages. All experiments were conducted at $15^{\circ} \mathrm{C}$. Nauplii and copepodite data are from Koski et al. (1998, unpubl.)

\begin{tabular}{|c|c|c|c|c|}
\hline \multicolumn{2}{|c|}{ Diet } & \multicolumn{2}{|c|}{ - Mortality } & \multirow[b]{2}{*}{ Adults } \\
\hline Food species trat & $\begin{array}{l}\text { Concen- } \\
\text { on }\left(\mu \mathrm{C} \mathrm{C}^{-1}\right)\end{array}$ & Nauplii & $\begin{array}{l}\text { Cope- } \\
\text { podites }\end{array}$ & \\
\hline \multicolumn{5}{|l|}{ (a) T. longicornis } \\
\hline FW & 0 & 67 & & 24 \\
\hline Rhodomonas sp. & 50 & 25 & & 8.4 \\
\hline Rhodomonas sp. & $>300$ & 5.2 & 8.3 & 2.1 \\
\hline Dunaliella sp. & $>300$ & & & $1.3-2.5$ \\
\hline Amphidinium sp. & $>300$ & 22 & & 12 \\
\hline C. polylepis & $>300$ & 59 & & 12 \\
\hline Synechococcus sp. & $>300$ & 51 & & 15 \\
\hline \multicolumn{5}{|l|}{ (b) P. elongatus } \\
\hline Fw & 0 & 67 & & 13 \\
\hline Rhodomonas sp. & 50 & 16 & & 6.2 \\
\hline Rhodomonas sp. & $>300$ & 6.5 & 9.1 & 4.1 \\
\hline Dunaliella sp. & $>300$ & 10 & & 5.3 \\
\hline Amphidinium sp. & $>300$ & $6-9$ & & 15 \\
\hline C. polylepis & $>300$ & 14 & & \\
\hline Synechococcus sp. & $>300$ & 55 & & \\
\hline
\end{tabular}


Acknowledgements. We wish to thank N. Schogt for taking care of the algae and copepod cultures, S. Gonzalez for the $\mathrm{C}: \mathrm{N}$ analysis of algae, and G. Herndl and W. Kimmerer for constructive comments on the previous version of this manuscript. M.K. was financed by the Academy of Finland.

\section{LITERATURE CITED}

Ahlgren G, Gustafsson IB, Boberg M (1992) Fatty acid content and chemical composition of freshwater microalgae. J Phycol 28:37-50

Amarasinghe PB, Boersma M, Vijverberg J (1997) The effect of temperature, and food quantity and quality on the growth and development rates in laboratory-cultured copepods and cladocerans from a Sri Lankan reservoir. Hydrobiology 350:131-144

Båmstedt U, Håkanson JL, Brenner-Larsen J, Björnsen PK, Geertz-Hansen O, Tiselius P (1990) Copepod nutritional condition and pelagic production during autumn in Kosterfjorden, western Sweden. Mar Biol 104:197-208

Bonnet D, Carlotti F (2001) Development and egg production in Centropages typicus (Copepoda: Calanoida) fed different food types: a laboratory study. Mar Ecol Prog Ser 224: 133-148

Brett MT, Müller-Navarra DC, Park SK (2000) Empirical analysis of the effect of phosphorus limitation on algal food quality for freshwater zooplankton. Limnol Oceanogr 45:1564-1575

Cadée GC, Hegeman J (1991) Phytoplankton primary production, chlorophyll and species composition, organic carbon and turbidity in the Marsdiep in 1990, compared with foregoing years. Hydrobiol Bull 25:29-35

Dagg M (1977) Some effects of patchy food environments on copepods. Limnol Oceanogr 22:99-107

Davis CS, Alatalo P (1992) Effects of constant and intermittent food supply on life-history parameters in a marine copepod. Limnol Oceanogr 37:1618-1639

DeMott WR, Müller-Navarra D (1997) The importance of highly saturated fatty acids in zooplankton nutrition: evidence from experiments with Daphnia, a cyanobacterium and lipid emulsions. Freshw Biol 38:649-664

Fraser AJ, Sargent JR, Gamble JC (1989) Lipid class and fatty acid composition of Calanus finmarchicus (Gunnerus), Pseudocalanus sp., and Temora longicornis Muller from a nutrient-enriched seawater enclosure. J Exp Mar Biol Ecol 130:81-92

Gill CW, Harris RP (1987) Behavioural responses of the copepods Calanus helgolandicus and Temora longicornis to dinoflagellate diets. J Mar Biol Assoc UK 67:785-801

Guillard RRL (1975) Culture of phytoplankton for feeding marine invertebrates. In: Smith WL, Chanley MH (eds) Culture of marine invertebrate animals. Plenum Press, New York, p 29-60

Håkanson JL (1984) The longterm and shortterm feeding conditions in field-caught Calanus pacificus, as determined from the lipid content. Limnol Oceanogr 29:794-804

Harris RP, Paffenhöfer GA (1976) Feeding, growth and reproduction of the marine planktonic copepod Temora longicornis Müller. J Mar Biol Assoc UK 67:785-801

Hart RC (1996) Naupliar and copepodite growth and survival of 2 freshwater calanoids at various food levels: demographic contrasts, similarities and food needs. Limnol Oceanogr 41:648-658

Hassett RP, Landry MR (1990) Effects of diet and starvation on digestive enzyme activity and feeding behaviour of the marine copepod Calanus pacificus. J Plankton Res 12:991-1010
Hessen DO (1992) Nutrient element limitation of zooplankton production. Am Nat 140:799-814

Huntley ME, Sykes P, Rohan S, Marin V (1986) Chemicallymediated rejection of dinoflagellate prey by the copepod Calanus pacificus and Paracalanus parvus: mechanism, occurrence and significance. Mar Ecol Prog Ser 28:105-120

Huntley ME, Ciminiello P, Lopez MDG (1987) Importance of food quality in determining development and survival of Calanus pacificus (Copepoda: Calanoida). Mar Biol 95: 103-113

Ianora A (1998) Copepod life history traits in subtemperate regions. J Mar Syst 15:337-349

Ianora A, Poulet S (1993) Egg viability in the copepod Temora stylifera. Limnol Oceanogr 38:1615-1626

Ianora A, Poulet SA, Miralto A, Grottoli R (1996) The diatom Thalassiosira rotula affects reproductive success in the copepod Acartia clausi. Mar Biol 125:279-286

Kiørboe T (1998) Population regulation and role of mesozooplankton in shaping marine pelagic food webs. Hydrobiologia 363:13-27

Klein Breteler WCM (1980) Continuous breeding of marine pelagic copepods in the presence of heterotrophic dinoflagellates. Mar Ecol Prog Ser 2:229-233

Klein Breteler WCM, Gonzalez SR (1986) Culture and development of Temora longicornis (Copepoda: Calanoida) at different conditions of temperature and food. Syllogeus 58:71-84

Klein Breteler WCM, Fransz HG, Gonzalez SR (1982) Growth and development of four calanoid copepod species under experimental and natural conditions. Neth J Sea Res 16: 195-207

Klein Breteler WCM, Gonzalez SR, Schogt N (1995) Development of Pseudocalanus elongatus (Copepoda, Calanoida) cultured at different temperature and food conditions. Mar Ecol Prog Ser 119:99-110

Klein Breteler WCM, Schogt N, Baas M, Schouten S, Kraay GW (1999) Trophic upgrading of food quality by protozoans enhancing copepod growth: role of essential lipids. Mar Biol 135:191-198

Koski M, Klein Breteler W, Schogt N (1998) Effect of food quality on rate of growth and development of the pelagic copepod Pseudocalanus elongatus (Copepoda, Calanoida). Mar Ecol Prog Ser 170:169-187

Koski M, Engström J, Viitasalo M (1999) Reproduction and survival of the calanoid copepod Eurytemora affinis on a diet of cyanobacterium Nodularia sp. Mar Ecol Prog Ser 186:187-197

Leblond JD, Chapman PJ (2000) Lipid class distribution of highly unsaturated long chain fatty acids in marine dinoflagellates. J Phycol 36:1103-1108

Lopez MDG (1991) Molting and mortality depend on age and stage in naupliar Calanus pacificus: implication for development time of field cohorts. Mar Ecol Prog Ser 75:79-89

Lopez MDG (1996) Effect of starvation on development and survivorship of naupliar Calanus pacificus (Brodsky). J Exp Mar Biol Ecol 203:133-146

Mauchline J (1998) The biology of calanoid copepods. Adv Mar Biol 33:1-707

Nielsen TG, Kiørboe T, Bjørnsen PK (1990) Effects of a Chrysochromulina polylepis subsurface bloom on the planktonic community. Mar Ecol Prog Ser 62:21-35

Ohman MD, Wood SN (1995) The inevitability of mortality. ICES J Mar Sci 52:517-522

Ourisson G, Rohmer M (1987) Procaryotic hopanoids and other polyterpenoid sterol surrogates. Annu Rev Microbiol 41:301-333

Paffenhöfer GA (1976) Feeding, growth and food conversion 
of the marine planktonic copepod Calanus helgolandicus. Limnol Oceanogr 21:39-50

Paffenhöfer GA, Harris RP (1976) Feeding, growth and reproduction of the marine planktonic copepod Pseudocalanus elongatus Boeck. J Mar Biol Assoc UK 56:327-344

Peeters JCH, Haas HA, Peperzak L, Vries I (1993) Nutrients and light as factors controlling phytoplankton biomass on the Dutch Continental Shelf (North Sea) in 1988-1990. Report DGW-93.004. Directorate-General for Public Works and Water Management, Den Haag

Sterner RW, Robinson JL (1994) Thresholds for growth in Daphnia magna with high and low phosphorus diet. Limnol Oceanogr 39:1228-1232

Støttrup JG, Jensen J (1990) Infuence of algal diet on feeding

Editorial responsibility: Otto Kinne (Editor),

Oldendorf/Luhe, Germany and egg-production of the calanoid copepod Acartia tonsa Dana. J Exp Mar Biol Ecol 141:87-105

Urabe J, Watanabe Y (1993) Implications of sestonic elemental ratio in zooplankton ecology: reply to the comment by Brett. Limnol Oceanogr 38:1337-1340

Uye S (1988) Temperature-dependent development and growth of Calanus sinicus (Copepoda: Calanoida) in the laboratory. Hydrobiology 167/168:285-293

Verity PG, Smetacek V (1996) Organism life cycles, predation, and the structure of marine pelagic ecosystem. Mar Ecol Prog Ser 130:277-293

Von Elert E, Wolffrom T (2001) Supplementation of cyanobacterial food with polyunsaturated fatty acids does not improve growth of Daphnia. Limnol Oceanogr 46:1552-1558

Submitted: February 20, 2002; Accepted: July 1, 2003

Proofs received from author(s): November 26, 2003 